\title{
Consideration of Ecological Factors in Compulsory Purchase of Land when Placing Objects of Transport Infrastructure
}

\author{
Alina Lizunova ${ }^{1}$ \\ 1 Department of Land Management and Cadaster, Kyiv National University of Construction and Architecture, \\ 03037 Povitroflotskiy Ave 31, Kyiv, Ukraine, e-mail: alinalizunova@ukr.net
}

\begin{abstract}
While developing the projects for the construction of new and reconstruction of the existing roads, there is a probability of using privately owned land. In these cases, the mechanism of alienation of the private land plots is used to meet the public needs. Among the list of social needs, in the first place, there is a need for the land plots during construction, major repairs, reconstruction and maintenance of transport infrastructure objects, in particular roads. While designing the road construction and reconstruction projects, the technical-economic and transport-operational characteristics of the design object should be determined in conjunction with the protection of the environment and the rational use of natural resources. The article deals with the issues of assessing the impact of the road construction on the environment and the measures to reduce the level of pollution of the environment by introducing the environmental, technological, sanitary-technical and organizational measures.
\end{abstract}

Keywords: compulsory purchase, transport infrastructure, public roads, protection of the environment, environmental impact, environmental safety.

\section{INTRODUCTION}

Privately owned land can be used for the construction of new and reconstruction of existing linear objects of transport infrastructure. While developing the projects for the construction of new and reconstruction of existing roads, there is a probability of using privately owned land. In these cases, the mechanism of compulsory purchase of land plots of private property is used to meet the public needs in accordance with the Law of Ukraine "On compulsory purchase of land plots, other objects of real estate that are located on them, which are in private ownership, for public needs or for reasons of public necessity" [Law N1559-VI]. According to this Law, the compulsory purchase of land is the transfer of ownership of land, other real estate objects that are located on them, owned by individuals or legal entities, for payment in state or communal ownership by means of their redemption or compulsory alienation for the needs of the state, territorial community, or society as a whole. The object of compul- sory purchase is a land plot (its part), a residential building, other buildings, structures, perennial plantations, which are located on it and are owned by natural or legal persons.

The comparison of land plots alienation in Ukraine and European countries, the results of which are shown in Figure 1, allows us to conclude that they are similar in Ukraine to those of Europe, with some differences, namely, the Land Courts and Organizations interested in alienation, do not have the authority to initiate the process of alienation of land plots [Kalbro, 2007, Kalbro, Sjödin, Norell, and Paulsson, 2008].

After analyzing the legally defined list of public needs, the results of which are shown in Figure 2, it was established that Ukraine differs from the European countries by the fact that its list of legally recognized social needs, such as: construction of objects providing space activities and construction of public buildings schools, libraries, hospitals, factories, religious institutions, state and municipal housing, is not taken into account [FAO 2008, Viitanen, 2007]. 


\section{GENERAL}

DIFFERENCES

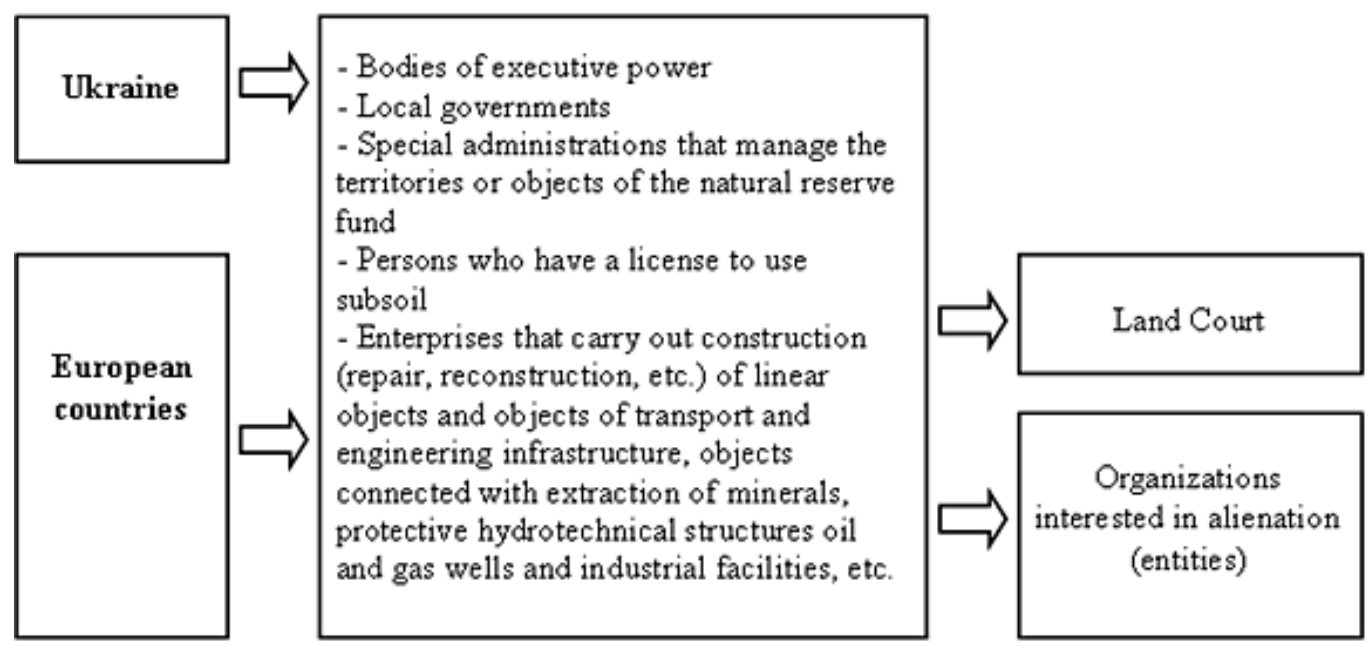

Figure 1. Powers of alienation of land plots

The powers of compulsory purchase of land plots in Ukraine are granted to executive authorities and local self-government bodies. They can be implemented in the course of construction, major repairs, reconstruction and maintenance of linear objects and objects of transport and energy infrastructure (roads, bridges, overpasses, oil, gas and water pipelines, power lines, communications, airports, seaports, oil and gas terminals, power plants) and facilities necessary for their exploitation.

According to the legally defined classification of linear objects of transport infrastructure, shown in Figure 3, one of the objects of classification is roads. In turn, roads are divided into: public roads, streets and roads of cities and other settlements; departmental (technological) roads; roads in private territories and roads of defensive significance. The focus will be on public roads.

According to the official data of the Ministry of Infrastructure of Ukraine, the road network of public roads of Ukraine has a length of 169 thousand $\mathrm{km}$ and consists of state and local roads. The structure of the public roads network of Ukraine is shown in Figure 4 and Table 1.

Out of the total length of roads with hard cover, the roads with improved coating types (concrete cement, asphalt concrete, black highways) make up $79 \%$, the rest - with transitional coating types (white crushed stone and gravel, pave-

\section{GENERAL}

\section{DIFFERENCES}

\begin{tabular}{|l|l|l|l|}
\hline Ukraine \\
European \\
countries
\end{tabular}$\longrightarrow \begin{aligned} & \text { - Ensuring national security and defense } \\
& \text { and consular offices } \\
& \text { - Construction and maintenance of linear } \\
& \text { objects and objects of transport and } \\
& \text { engineering infrastructure }\end{aligned}$

Figure 2. Legally defined list of public needs 


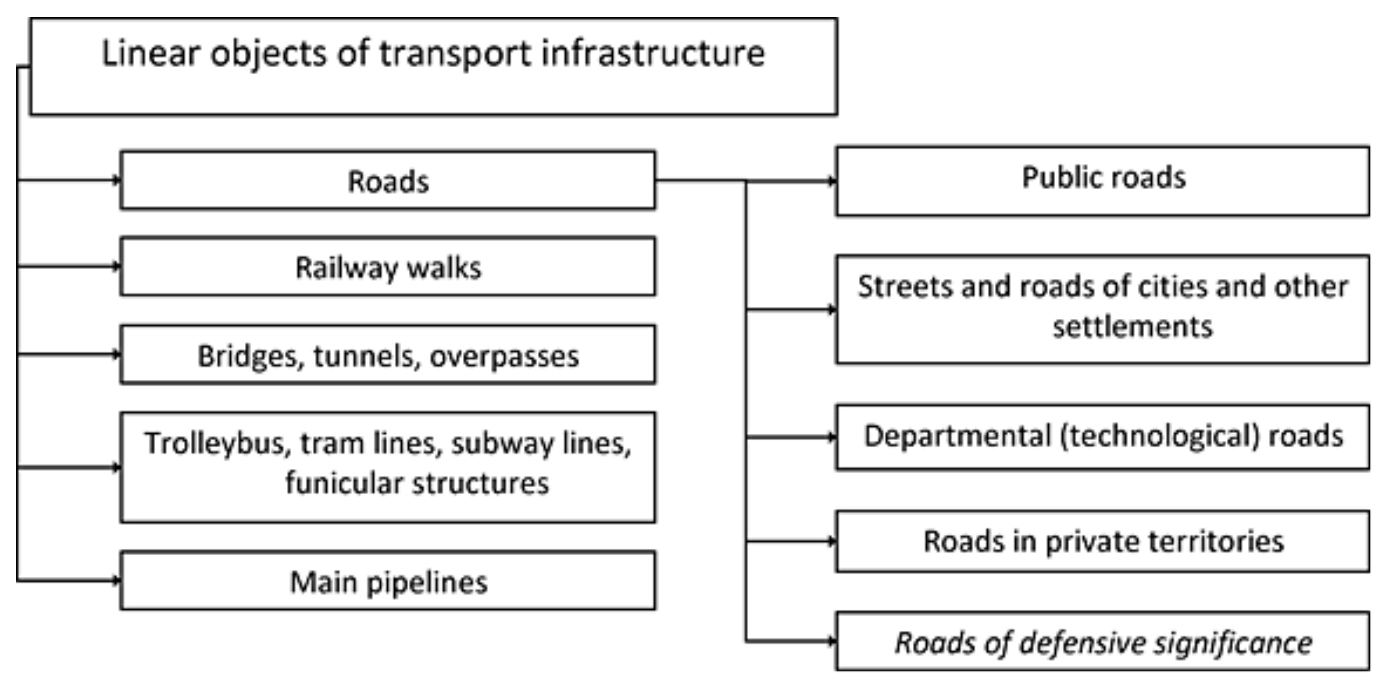

Figure 3. Classification of linear objects of transport infrastructure

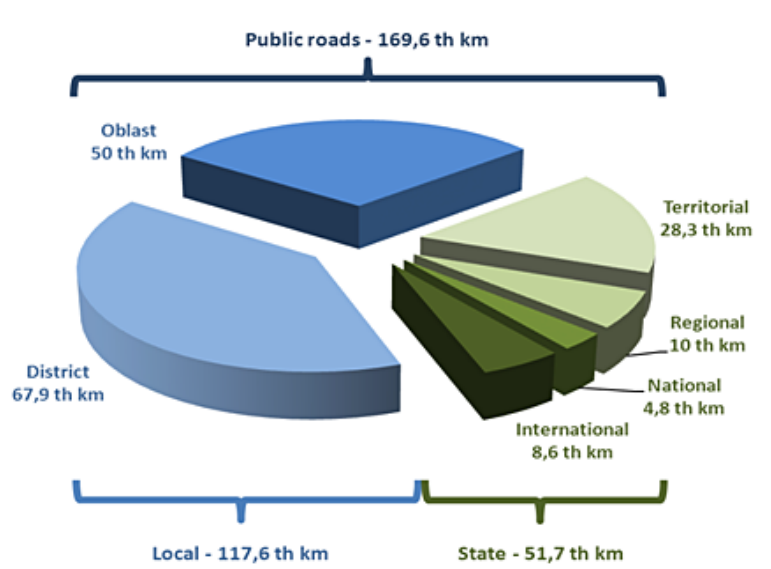

Figure 4. Structure of the public roads network of Ukraine

Table 1. The length of public roads

\begin{tabular}{|c|c|}
\hline \multicolumn{1}{|c|}{ Name } & Length \\
\hline Public roads: & 169.6 th $\mathrm{km}$ \\
\hline - Local: & 117.9 th $\mathrm{km}$ \\
\hline - Oblast & 50 th $\mathrm{km}$ \\
\hline - District & 67.9 th km \\
\hline - State: & 51.7 th $\mathrm{km}$ \\
\hline - International & 8.6 th km \\
\hline - National & 4.8 th $\mathrm{km}$ \\
\hline - Regional & 10 th $\mathrm{km}$ \\
\hline - Territorial & 28.3 th $\mathrm{km}$ \\
\hline
\end{tabular}

ment). Distribution of public roads of Ukraine by types of coatings is shown in Figure 5 and Table 2. Due to limited funding, about 90 percent of public roads have not been repaired for more than 30 years. Thus, the public roads do not meet modern requirements as to the strength $(39.2 \%)$ and evenness $(51.1 \%)$ and are in need of renovation. During land plot alienation, the tasks that re- quire an optimal option in the presence of various factors are often encountered. These factors can be divided into the following main groups: economic, legal, environmental, planning, geographic, engineering, technological and socio-cultural [Lizunova and Mykhalova 2011, 2012].

One of the main groups of factors influencing the location of linear objects are the environmental ones. Let us consider the influence of both environmental factors on the design of the highway, and the environmental impact of the construction itself on the environment in greater detail.

\section{ENVIRONMENTAL IMPACT}

The main criterion for choosing the optimal variant route road is the minimal payback period of investment, given priority to ensure environmental safety requirements, mandatory compliance with environmental standards and regulations [Lizunova and Mykhalova, 2013, Belej and Walacik, 2008]. The technical classification of roads by categories, depending on the estimated average annual daily promising traffic intensity in Ukraine [Law N2862-IV], is given in Table 3. While designing the projects of roads of state importance and the roads of local importance of the III category and above, as a rule, it is necessary to set aside the settlements. If it is impossible, the construction detours the settlements of engineering and geological, technical, social or economic reasons, in coordination with local governments, road trail through the city highways [Law N232/94-BP].

While developing the projects for the construction and reconstruction of roads and other 


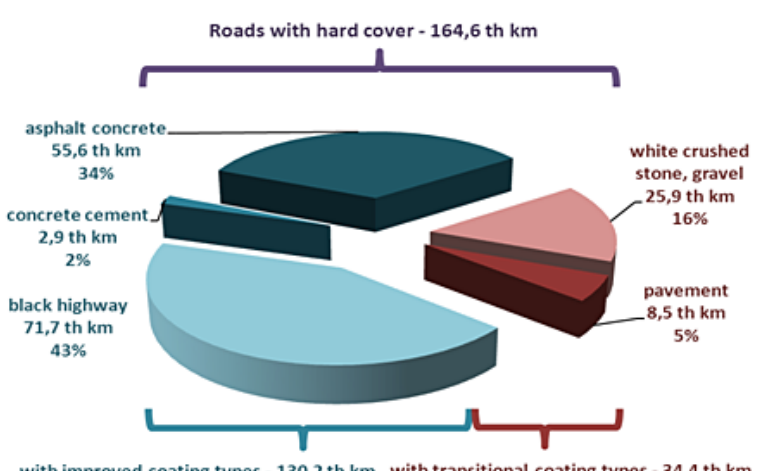

Figure 5. Distribution of public roads of Ukraine by types of coatings

Table 2. The length of roads with hard cover

\begin{tabular}{|c|c|}
\hline Name & Length \\
\hline Roads with hard cover: & 164.6 th $\mathrm{km}$ \\
\hline - with improved coating types: & 130.2 th $\mathrm{km}$ \\
\hline - black highway & 71.7 th km \\
\hline - concrete cement & 2.9 th $\mathrm{km}$ \\
\hline - asphalt concrete & 55.6 th km \\
\hline - with transitional coating types: & 34.4 th $\mathrm{km}$ \\
\hline - white crushed stone, gravel & 25.9 th km \\
\hline - pavement & 8.5 th $\mathrm{km}$ \\
\hline
\end{tabular}

Table 3. Technical classification of roads of Ukraine

\begin{tabular}{|c|l|l|}
\hline \multirow{2}{*}{$\begin{array}{c}\text { Roads } \\
\text { category }\end{array}$} & \multicolumn{2}{|c|}{ Estimated prospective traffic intensity, car / day } \\
\cline { 2 - 3 } & in transport units & in reduced units to car \\
\hline I-a-I-b & more than 10,000 & more than 14,000 \\
\hline II & from 3,000 to 10,000 & from 5,000 to 14,000 \\
\hline III & from 1,000 to 3,000 & from 2,500 to 5,000 \\
\hline IV & from 150 to 1,000 & from 300 to 2,500 \\
\hline V & to 150 & to 300 \\
\hline
\end{tabular}

road objects, technical-economic and transportoperational characteristics of the design object should be solved along with the issue of environmental protection and rational use of natural resources. While assessing the impact of the construction of road on the environment, it is necessary to consider the physical-geographical features of the area as well as the road construction track and overall characteristics of the road; to evaluate the impact of the construction of the road on the natural, social and technogenic environment, to develop comprehensive measures to ensure the regulatory status of the environment and its safety [Law N2344-III].

Thus, the following components of the environment are distinguished:
- climate and microclimate;

- air environment;

- geological environment;

- aqueous medium;

- soils;

- flora and fauna, protected areas.

Only those components and the objects of the environment that are affected by the construction of the road, as well as those the current state of which does not conform to the normative one, are considered. For each component in the environment, the following are presented [Law N1264-XII]:

- substantiation of the necessity of evaluating its characteristics;

- list of impacts and their characteristics, which also contain qualitative and quantitative parameters, degree of danger;

- justification of the boundaries of the impacts of construction of the road, data on the size of sanitary protection zones and gaps;

- the characteristics of the retrospective, contemporary and predicted environmental conditions and their assessment in the background and normative indicators, taking into account possible emergency situations;

- substantiation of measures for prevention and limitation of negative influences, assessment of their effectiveness and characteristics of residual impacts;

- analysis of constraints on the construction of road objects under the conditions of the environment; the volume of necessary engineering training of the territory.

- In the analysis of the air environment, the following aspects are considered:

- description of sources of pollutant emissions into the atmosphere, scheme of their placement, calculations of mass emissions;

- data pertaining to the background pollution of the atmosphere in the area of the road location;

- estimation of the level of air pollution caused by the road;

- assessment of atmospheric air pollution under adverse meteorological conditions;

- assessment of contamination in case of possible emergency situations;

- substantiation of the levels of permissible emissions and measures to prevent or reduce the formation and release of substances contaminating atmospheric air;

- proposals on determining the size of the sanitary protection zone on the basis of calculations of air pollution from the road; 
- organization of monitoring the state of atmospheric air, methods and means of control.

It is also necessary to analyze the noise characteristics from the road, such as: data of actual measurements of the existing background noise level (if any); estimated noise levels from the highway; justification of measures for noise reduction; substantiation of requirements for noise protection measures.

The impact of road construction on soils should also be analyzed, taking into account the features of land use, the availability of valuable agricultural land areas, chemical, biological and radioactive contamination, vibration, emergence of dangerous engineering-geological processes as well as the phenomena and other factors that negatively affect the state of the soil.

The levels of the road impact on the environment are estimated within the adjacent part of the traffic area, which is subject to direct or indirect environmental impact of the projected object. They are divided as follows: the lane, the protective strip and the reserve technology strip. The estimated dimensions of the impact strip, the protective strip, reserve-technology strips are shown in Table 4 [GBN B.2.3-218-007].

The estimated dimensions of roadside lanes on roads are determined by the results of the forecast (for a 20-year perspective) of pollutant emissions and the spread of physical activity.

An assessment of the road construction impact on the natural environment, carried out within the limits of the actual availability of materials and data, should include: the characteristics of the current state of the environment of the construction site; substantiation of environmental and social advantages of the chosen construction option; analysis of potential sources, varieties and parameters of influence; justification of the estimated sizes of lanes; forecast assessment of the changes in the state of the environment; substantiation of

Table 4. The estimated dimensions of the impact strip, the protective strip, reserve-technology strips in Ukraine

\begin{tabular}{|l|c|c|c|}
\hline $\begin{array}{l}\text { Name of the } \\
\text { adjacent territory } \\
\text { affected by the } \\
\text { road }\end{array}$ & \multicolumn{3}{|l|}{$\begin{array}{l}\text { Distance from the edge of the roadway } \\
\text { for roads of different ecological } \\
\text { classes, m }\end{array}$} \\
\cline { 2 - 4 } & I class & II class & III class \\
\hline Impact strip & $3000 / 1500$ & $2000 / 1000$ & 600 \\
\hline Protective strip & $300 / 200$ & $150 / 90$ & $60 / 30$ \\
\hline $\begin{array}{l}\text { Reserve- } \\
\text { technological strip }\end{array}$ & 30 & 12 & 7.5 \\
\hline
\end{tabular}

a set of measures to reduce the levels of negative impacts on the population and the natural environment; the analysis of the acceptability of the expected residual environmental impact; an estimation of influence of the projected activity at the stage of construction and operation.

\section{DISCUSSION}

During construction, reconstruction and overhaul of the road, the main source of environmental impacts involves technological processes and construction machinery, and when the road is used - vehicles. The influence of the road on the environment is divided into the influence during construction work and during its operation (Figure 6) [GBN V.2.3-218-007:2012].

Let us consider the influence of construction and operation of the road on each component of the environment in more detail:

- air environment: emissions from exhaust gases from construction equipment and vehicles, and solid residues from wear of road tires and road surfaces;

- acoustic environment: noise, vibration from work of machines, mechanisms and motor transport;

- geological environment: possible occurrence and activation of exogenous processes;

- hydro-geological environment: possible temporary and permanent changes in the regime, levels of groundwater and groundwater, their chemical pollution;

- landscapes: changes of local landscapes, implementation of anti-erosion and anti-landslide measures, placement of excavations and embankments, the development of quarries;

- water environment: possible temporary and permanent changes in runoff and water levels, violation of channel processes and the development of abrasion, pollution of the aquatic environment with the sewage containing petroleum products and other chemical compounds, contamination by garbage and silting of channels, discharges of storm and melt waste from road cover and artificial structures;

- soil: removal of soil vegetation, degradation of soils due to flat erosion and changes in physical and mechanical properties due to earthworks, pollution by the sewage containing petroleum products and other chemical compounds, pollution by building waste, pollution by household rubbish; 


\begin{tabular}{|l|l|l|l|}
\hline \multicolumn{2}{|c|}{ road operation } & road construction & Impact \\
\hline indirect impact & direct impact & direct impact & \\
\hline & & & air environment \\
\hline & & & acoustic environment \\
\hline & & & geological environment \\
\hline & & $\begin{array}{l}\text { hydro geological } \\
\text { environment }\end{array}$ \\
\hline & & & landscapes \\
\hline & & & water environment \\
\hline & & & soil \\
\hline & & & $\begin{array}{l}\text { flond resources } \\
\text { protected sites }\end{array}$ \\
\hline & & $\begin{array}{l}\text { the surrounding social } \\
\text { environment }\end{array}$ \\
\hline & & $\begin{array}{l}\text { the surrounding } \\
\text { technogenic }\end{array}$ \\
\hline
\end{tabular}

Figure 6. Influence of the construction and operation of the road on the components of the environment

- land resources: alienation of land for the construction of motor roads and artificial structures, temporary withdrawal of land for reserves, quarries, construction sites and technological passages;

- flora and fauna, protected sites: deforestation, shrubbery, habitat abnormalities, changes in the habitat conditions and the ways of wildlife migration, impact on biotopes, biological and ecological systems;

- the surrounding social environment: seizure of land for permanent and temporary use, demolition of buildings, inconvenience during construction, pollution of the air basin, man-made impact on historical and architectural monuments, changes in conditions of local and transit traffic;

- the surrounding technogenic environment: the influence of emissions, vibrations on buildings and structures, the violation of the operational reliability of elements of the man-caused environment, the formation of construction and household waste.

According to the Order of the Ministry of Health of Ukraine "On Approval of the State Sanitary Rules for Planning and Development of Human Settlements of Ukraine", the distance from the eaves of the roadbed of roads, depending on the category, must be at least $100 \mathrm{~m}$ to residential construction and gardening societies, for roads of category IV $-50 \mathrm{~m}$, with the provision of hygienic norms of air quality and noise levels on the respective territory. For protection against noise and gas pollution along roads, it is necessary to envisage strips of green plantations not less than $10 \mathrm{~m}$ wide [Order N173].

The distance from the edge of the passage of main roads to the red line of residential development should be established taking into account the provision of standard levels of noise and pollution of atmospheric air in residential building, but no less than $50 \mathrm{~m}$ [DBN V.2.3-5-2017]. Thus, the lane for road transport outside the settlement will be as shown in Table 5.

The width of the landing strip for road transport within the settlement is indicated in Table 6 [DBN V.2.3-16:2007]. Within the limits of the road alienation strip and red lines of city streets and roads it is prohibited: to locate any buildings or objects without the consent of the owners of roads and the State Motor Vehicle Inspection of Ukraine; to place containers and other containers for solid household and food waste; dust, damage the road surface, equipment, green plantations; burn garbage, fallen leaves and other waste, store them for long periods of time storage; to drop industrial, reclamation and sewage water into the system of road trapping; to install tents and arrange places for rest; to build new and repair existing networks within the "red lines" of streets and roads of cities and other settlements without the corresponding permission of local governments [DBN 360-92**].

Table 5. Characteristics of roads of Ukraine

\begin{tabular}{|c|c|c|c|}
\hline $\begin{array}{c}\text { Road } \\
\text { category }\end{array}$ & $\begin{array}{c}\text { The smallest } \\
\text { width of the } \\
\text { main site of } \\
\text { the cloth with a } \\
\text { certain number } \\
\text { of lanes, } \mathrm{m}\end{array}$ & $\begin{array}{c}\text { Security } \\
\text { zone, } \mathrm{m}\end{array}$ & $\begin{array}{c}\text { Approxi- } \\
\text { mate total } \\
\text { value, } \mathrm{m}\end{array}$ \\
\hline I-a & $28.5 ; 36.0 ; 43.5$ & $\begin{array}{c}\text { Not less } \\
\text { than 100 }\end{array}$ & 243.5 \\
\hline I-b & $28.5 ; 36.0$ & $\begin{array}{c}\text { Not less } \\
\text { than 100 }\end{array}$ & 236.0 \\
\hline II & 15.0 & $\begin{array}{c}\text { Not less } \\
\text { than } 100\end{array}$ & 215.0 \\
\hline III & 12.0 & $\begin{array}{c}\text { Not less } \\
\text { than } 100\end{array}$ & 212.0 \\
\hline IV & 10.0 & 50 & 110.0 \\
\hline V & 8.0 & About 50 & About 108.0 \\
\hline
\end{tabular}


Table 6. Width of the landing strip for roads of Ukraine

\begin{tabular}{|l|c|c|c|}
\hline Category of streets and roads & $\begin{array}{c}\text { The width of the main } \\
\text { site of the earth's } \\
\text { canvas, } \mathrm{m}\end{array}$ & Security zone, $\mathrm{m}$ & $\begin{array}{c}\text { Approximate total } \\
\text { value, } \mathrm{m}\end{array}$ \\
\hline Highway & $50-90$ & $\begin{array}{c}\text { Not less than 50 (included in the width } \\
\text { of the main site of the earth's cloth) }\end{array}$ & $50-90$ \\
\hline Highway all-city significance & $50-80$ & $\begin{array}{c}\text { Not less than 50 (included in the width } \\
\text { of the main site of the earth's cloth) }\end{array}$ & $50-80$ \\
\hline Highway of district significance & $40-50$ & $\begin{array}{c}\text { Not less than 50 (included in the width } \\
\text { of the main site of the earth's cloth) }\end{array}$ & $40-50$ \\
\hline Local streets (residential) & $15-35$ & - & $15-35$ \\
\hline Village and rural streets (roads) & $15-25$ & - & $15-25$ \\
\hline
\end{tabular}

\section{CONCLUSIONS}

In Ukraine, it is expedient to legislatively extend the powers of initiating alienation to meet the public needs. Granting powers to initiate the alienation of Land Courts and Organizations will accelerate the procedure and the consider litigation. It would also be desirable to increase the list of legally determined needs, taking into account current trends in the development of scientific and technological progress, and to draw on the experience of European countries.

As a result of the comparative analysis pertaining to the direct and indirect influence of the construction and operation of the road on the natural environment, it was established that:

- at the stage of road construction, there is an impact on all components of the environment;

- the use of the road does not affect the geological and hydro-geological environment and landscapes;

- road use also does not affect land resources, as the purchase of land plots takes place at the stage of road construction;

- indirect use of the road affects on flora and fauna, protected sites, the surrounding social and technogenic environment.

It is necessary to minimize the direct and indirect impacts during construction and use of the road to the environment by the implementing the following actions:

- laying a road bypassing settlements;

- arrangement of drainage and protective engineering structures;

- removal of the upper fertile soil layer for subsequent use;

- arrangement of specially designated places for refueling and maintenance of vehicles and road-building machines;

- land reclamation after the work is completed;
- prohibition of construction work at night;

- creation of new compensatory green plantations, including protective forest bands;

- the use of special engineering measures to protect buildings and structures from the effects of vibration (anti-vibration screens);

- collection and treatment of wastewater before discharge;

- use of the most modern environmentallyfriendly and non-waste resource-saving technologies.

\section{REFERENCES}

1. FAO. 2008. Compulsory Acquisition of Land and Compensation. FAO Land Tenure Studies 10. Rome: Food and Agriculture Organization of the United Nations, pp. 63.

2. Kalbro, T. 2007. Private Compulsory Acquisition and the Public Interest Requirement. Paper to the FIG (International Federation of Surveyors) Helsinki Seminar on Compulsory Purchase, 6-8 September.

3. Kalbro, T., Sjödin, E., Norell, L. \& Paulsson, J. 2008. Compulsory Acquisition and Compensation. Report from the Division of Real Estate Planning and Land Law, Royal Institute of Technology, Stockholm.

4. Law of Ukraine "On compulsory purchase of land plots, other objects of real estate that are located on them, which are in private ownership, for public needs or from the motives of social necessity" $\mathrm{N}$ 1559-VI dated 17.11.2009.

5. Law of Ukraine "On roads" N 2862-IV dated 8.09.2005.

6. Law of Ukraine "On Road Transport" N 2344-III dated 5.04.2001.

7. Law of Ukraine "On Transport” N 232/94-BP dated 10.11.1994.

8. Law of Ukraine "On the protection of the surrounding natural environment” № 1264-XII dated 25.06.1991. 
9. Lizunova A., Mykhalova M., 2012. Compulsory purchase of land plots for public needs as an integral part of sustainable development of territories. Urban Planning and Territorial Planning, 43, 10-215.

10. Lizunova A., Mykhalova M., 2013. Environmental damages, which must be compensated during the process compulsory purchase of land in Ukraine. Research people and actual tasks on multidisciplinary sciences: Materials of the 4th International Conference (Lozynets, Bulgaria, June 12-16, 2013), 173-176.

11. Lizunova A., Mykhalova M., 2011. Legal and spatial-technical aspects of compulsory purchase of land plots for public needs or motives of public necessity in Ukraine. Urban Planning and Territorial Planning, 42, 204-209.

12. Belej M. and Walacik M. 2008. Land Acquisition for Public Purpose in Poland on Example of Public Roads Construction. Available at: http://www.fig. net/pub/fig2008/papers/ts04b/ts04b_03_belej_walacik_2849.pdf.

13. Order of the Ministry of Health of Ukraine "On Approval of the State Sanitary Rules for Planning and Development of Human Settlements of Ukraine" N173 19.06.1996.
14. Sector construction norms of Ukraine (GBN in Ukrainian) V.2.3-218-007:2012 "Constructions of transport environmental requirements for roads. Designing State Agency of Motor Roads of Ukraine" Ukravtodor 2012.

15. State construction norms of Ukraine (DBN in Ukrainian) 360-92** “City planning. Planning and building urban and rural settlements" Minbudarchitecture Ukraine, 1993.

16. State construction norms of Ukraine. (DBN in Ukrainian) V.2.3-16:2007 "Constructions of transport. Standards withdrawal land sites for the construction (reconstruction) of motor vehicles roads" Minregionbud Ukraine, 2007.

17. State construction norms of Ukraine (DBN in Ukrainian) V.2.3-4:2015 "Roads. Design and construction" Minregionbud Ukraine, 2015.

18. State construction norms of Ukraine. (DBN in Ukrainian) V.2.3-5-2017 "Streets and roads inhabited cities" Ministry regional development, construction and housing and communal services farms Ukraine, 2017.

19. Viitanen K. 2007. Compulsory Purchase and Compensation in Land Acquisition and Taking. Gim International, 21(11), pp. 57. 